DOI: https://doi.org/10.31933/dijemss.v3i1

Received: $10^{\text {th }}$ August 2021, Revised: $15^{\text {th }}$ September 2021, Publish: $15^{\text {th }}$ October 2021

\begin{tabular}{|c|c|c|}
\hline PINASTI & $\begin{array}{l}\text { DIJEMSS } \\
\text { DINASTI INTERNATIONAL JOURNAL } \\
\text { OF EDUCATION MANAGEMENT AND } \\
\text { SOCIAL SCIENCE }\end{array}$ & $\begin{array}{r}\text { https://dinastipub.org/DIJEMSs } \\
\text { editor@dinastipub.org } \\
08117401455\end{array}$ \\
\hline
\end{tabular}

\title{
IMPROVING BANKING IMAGE THROUGH SERVICE QUALITY AT BNI KC SIMPANG RIMBO JAMBI CITY
}

\author{
Gupron Gupron', Muhammad Reza Putra ${ }^{2}$ \\ ${ }^{1}$ Lecturer of Universitas Batanghari, Jambi, Indonesia, email: gupron@ unbari.ac.id \\ ${ }^{2}$ Ph.D Student, Universiti Kebangsaan Malaysia, Malaysia
}

\section{Corresponding Author: Gupron Gupron ${ }^{1}$}

\begin{abstract}
The purpose of this study was to analyze the effect of service quality on banking image at BNI KC Simpang Rimbo Jambi City. The population in this study were customers of BNI KC Simpang Rimbo Jambi City, totaling 9,359 customers until 2020. The size or number of samples in this study was determined based on the theory developed by Slovin with a margin of error of $10 \%$ so that a sample size of 100 customers was obtained. The approach in this study uses a quantitative approach with survey methods and uses simple linear regression equation data analysis assisted by SPSS 21.0 software for windows. However, before the analysis is carried out, the data quality test is first carried out through validity and reliability tests and classical assumption tests. Then test the hypothesis through t test (partial). From the results of the analysis concluded that the quality of service has a positive and significant effect on the image of the bank.
\end{abstract}

Keywords: Service Quality, and Bank Image

\section{INTRODUCTION}

A bank is a business entity that collects public funds, then places these funds in the form of savings and distributes them back to the community, both in the form of deposits and in the form of credit. In addition, in general functions, banks basically have a role as an agency for collecting funds, distributing funds, and providing financial services (Yandi, 2019).

In running its business, the bank always considers several aspects in making decisions to provide maximum service to customers. Where some of these aspects include the image of the bank itself. Image is the public's perception of the company or its products (Kotler and Keller, 2012). Image is the perception or perspective of the customer to the company based on the attributes attached to the company.

Corporate image is the general perception held by an organization by a group or groups (Balmer, 1995) or the net result of the interaction of all experiences, impressions, beliefs, feelings, and knowledge that people have about the company (Worcester, 1997), has become the focus marketing specialists, especially in various service sectors for many years. The importance of 
corporate image in the financial services sector stems mainly from the fact that corporate image is seen as a powerful instrument for influencing customers. In situations when there is little difference in price and consumers are flooded with an increasing volume of information, the image as an impression created at a certain time at a certain level of abstraction (Cornelissen, 2000) increasingly assumes the role of factors that make subjective customer orientation easier and their decisions. simpler. In addition, in the financial services sector the acquisition of a strong corporate image is the most effective type of differentiation (Balmer \& Stotvig, 1997).

A bank can differentiate itself from competitors by providing high quality services. This is supported by the opinion of Sicillia, M (2019) in her research which suggests that a company's image can be influenced by providing quality services. Because quality service is one of the factors that can determine the success of a bank, namely by providing a sense of security and comfort to its customers. With a sense of security and comfort, it will form a good image for customers. In order for the research to have a clear direction, the purpose of this study is to analyze the effect of service quality on the bank's image.

\section{LITERATURE REVIEW Theoritical Review}

Image is what consumers think or feel when they hear or see the name of a brand or in essence what consumers have learned about the brand (Supranto, 2011). According to Simamora (2007) that the image is a perception that is relatively consistent in the long term (enduring perception), it is not easy to form an image, so that once it is formed, it will be difficult to change it. According to Ali, H (2012) image is the result of evaluation in a person based on perception and understanding of the image that has been processed, organized, and stored in one's mind. Image can be measured through a person's opinion, impression or response with the aim of knowing exactly what is in the mind of each individual about an object, how they understand it, and what they like or dislike about the object.

A good corporate image is an asset for most companies because the company's image has an impact on customer perceptions of the communications and operations of a company that respects customers. Gronroos (2001) states that image has two functions, namely: 1) corporate image is a communication with various expectations; and 2) corporate image is a function of the best experience as customer expectations.

According to Sciffman and Kanuk (2010) there are several image-forming factors, namely as follows: 1) Quality and quality, related to the quality of goods offered by manufacturers with certain brands; 2) Can be trusted or relied upon, relating to opinions or agreements formed by the community about a product that is consumed; 3) Usefulness or benefits, which are related to the function of a product that can be utilized by consumers; 4) Services, which are related to the task of producers in serving their consumers; 5) Risk, related to the size of the result of profit and loss that may be experienced by consumers; 6) Price, which in this case relates to the high or low or the amount of money spent by consumers to influence a product, can also affect the long-term image; and 7) The image owned by the brand itself, which is in the form of views, agreements, and information related to a brand of a particular product.

According to Flavian, Torres and Guinaliu in Ali, H (2012) in their research on measuring banking image produced four elements that can form a banking image, namely access to services, service offered, personal contact, security and reputation, which will be used in this study.

Quality is a dynamic condition associated with products, services, people, processes and the environment that meet or exceed expectations (Goetsch Davis in Siswoyo, 2011). According to the 
American Society for Quality Control in Kotler (2012) service quality is the totality of characteristics and characteristics of a product or service that affects its ability to satisfy stated or implied needs. Service quality has been conceptualized as the difference between customer expectations regarding the service to be received and the perception of the service received (Parasuraman et al. in Akbar and Parves, 2009).

According to Kasmir (2007) several definitions related to service quality are: 1) Excellent: the standard of performance obtained; 2) Customer: individual, group, department, or company that receives, pays for the service output (service or system); 3) Service: the main or complementary activities that are not directly involved in the process of making the product but rather determine the service transaction between the buyer and the seller; 4) Quality: something that is specifically tangible or intangible from the nature of the product or service; 5) Consistency: there is no variation and all services run according to predetermined standards; 6) Levels: a statement of the system used to monitor and evaluate; and 7) Delivery: providing the right service in the right way and at the right time.

Meanwhile, according to Parasuraman et al (1989) service quality can be identified through SERVQUAL as follows: 1. Physical evidence (tangibles), in the form of appearance of physical facilities, equipment, and various communication materials. The appearance, facilities, and physical infrastructure of the company as well as the state of the surrounding environment are tangible evidence of the services provided by the service provider. In addition, based on research conducted by Jabnoun and Khalifa (2005) there are five dimensions of service quality based on factor analysis resulting in four dimensions: Personal Skills, Reliability, Value, and Image. These four dimensions are used by the author in measuring service quality in this study (Yandi, 2019).

\section{Framework of thinking}

Based on the research objectives, literature review, previous research and the relationship between variables, the analytical framework in this study is presented in the form of Figure 1. Where the service quality variable is the independent variable, the banking image variable is the dependent variable.

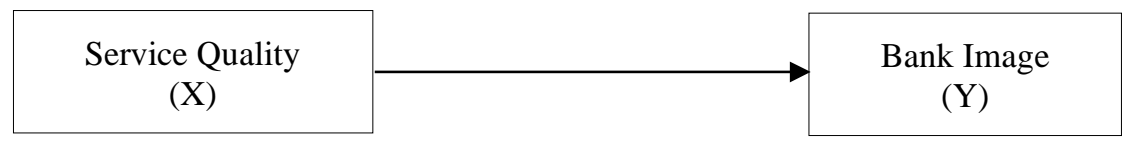

\section{Figure 1: Framework}

Based on the research objectives and theoretical review, the research hypotheses are:

1. Knowledge affects the interest in saving partially;

2. Lifestyle affects the interest in saving partially;

3. Religiosity partially affects the interest in saving; and

4. Knowledge, lifestyle, and religiosity simultaneously affect the interest in saving.

\section{Research Hypothesis}

Based on the theoretical framework above, the research hypothesis proposed in this study is "Service quality has an effect on banking image". 


\section{RESEARCH METHODS}

The population in this study were customers of BNI KC Simpang Rimbo Jambi City with a total of 9,359 in 2020 . The sample in this study was taken using the Slovin formula with a margin of error of $10 \%$, so that a sample of 98.94 was obtained and rounded to 100 .

This research is a quantitative research, because the data obtained in the form of numbers. The type of research is a questionnaire and the method used is about the phenomena that occur, the process is in the form of collecting and compiling data and analyzing data. Data were collected through filling out a questionnaire and analyzed further. This study consists of 3 (three variables), namely the exogenous variable (quality of service), to the endogenous variable of banking image.

To answer all the objectives in this study, the author uses multiple linear regression equations as an analytical technique, with the formula $\mathrm{Y}=\mathrm{a}+\mathrm{b} \cdot \mathrm{x}+\mathrm{e}$, where $\mathrm{Y}$ is the bank image variable, "b" the service quality variable coefficient (X). In order to simplify the process of data analysis in this study, the author uses the SPSS version 21.0 for windows application as an analytical tool.

After the data is processed, the next step is to test the hypothesis through a t-test to determine the effect partially, with a margin of error set at $5 \%$. However, before testing the hypothesis, the research instrument was first tested through validity and reliability tests, as well as testing classical assumptions through normality and heteroscedasticity tests.

\section{FINDINGS AND DISCUSSION Descriptive Analysis}

From the results of the survey conducted, basically the respondents gave responses agreeing and strongly agreeing with the statement submitted on each item of the statement in the questionnaire. This explains that the bank's image and service quality are in accordance with the respondents' perceptions. Based on the results of the analysis, it was found that:

1) From the survey results, it can be concluded that the image of the BNI KC Simpang Rimbo bank, Jambi City, has a fairly strong image in the eyes of the public. Where that image can be seen from good service access, namely ease of use of services, timeliness of transactions, convenience of service, bank operational schedules, and the possibility to file complaints/protests. In addition, from the services offered, the availability of the number of products and services, the attractiveness of the products and services offered, the interest in savings service products, the interest in loan payments, and the payment of service fees.

2) From the survey results, it can be concluded that the quality of service at BNI K Simpang Rimbo Jambi City is considered good. In the sense that employees are able to provide a sense of security and comfort to customers, can understand customer needs, have service conformity with what was promised, have good facilities and have a good image in the eyes of customers.

\section{Statistical Test Results}

A good regression equation basically must meet several assumptions that become the requirements of regression analysis. This means that a good regression equation must be normally distributed and there is no heteroscedasticity, but the data must be homogeneous. Each of these tests will be described one by one as follows. 
From the normality test conducted through the one Sample Kolmogorov Smirnov Test, a significant value of 0.846 was obtained. In theory, if the significant value obtained is $>5 \%$, then the data is declared to be normally distributed. Due to the significant value obtained at $0.846>$ $5 \%$, it can be stated that the data in this study were normally distributed, so it could be continued in the next stage.

The next assumption test in this study is through the heteroscedasticity test. In theory, a good regression equation does not occur heteroscedasticity, but homogeneity occurs. Where the results of the heteroscedasticity test can be detected through scatterplots, by looking at the spread of the plot points. If the plot points are randomly distributed and spread both above and below the number 0 on the $\mathrm{Y}$ axis, it can be concluded that there is no heteroscedasticity in the regression model. Because the plot points in this study spread randomly and spread both above and below the number 0 on the $\mathrm{Y}$ axis, so the regression model is feasible to use to predict the use of accommodation services based on the input of the independent variable.

From the results of the assumption test carried out all have been met, so that the regression equation model is considered good and can be continued for the next stage, namely by doing regression testing and hypothesis testing. As for the data processing performed using SPSS 21.0 for windows, the output is obtained as follows.

Table 1

Simple Linear Regression Analysis Results

\begin{tabular}{|c|c|c|c|c|c|}
\hline $\begin{array}{c}\text { Dependent } \\
\text { variable }\end{array}$ & $\begin{array}{c}\text { Independent } \\
\text { Variable }\end{array}$ & $\begin{array}{l}\text { Regression } \\
\text { Coefficient }\end{array}$ & $t_{\text {count }}$ & Sig & Conclusion \\
\hline \multirow{4}{*}{$\begin{array}{c}\text { Bank Image } \\
\text { (Y) }\end{array}$} & Constant (a) & 14,342 & & & - \\
\hline & Service quality (X) & 0,803 & 13,967 & 0,000 & Accepted \\
\hline & Adjusted $\mathrm{R}^{2}$ & & & & 0,662 \\
\hline & $\mathrm{t}_{\text {table }}$ & & & & 1,984 \\
\hline
\end{tabular}

Source: Output SPSS 23.0 for windows

From table 1 above, the results of multiple linear regression equations are obtained: $\mathrm{Y}=\mathrm{a}$ + b. $\mathrm{x}+\mathrm{e}=14,342+0,803 \cdot \mathrm{X} 2+\mathrm{e}$. Description: $\mathrm{Y}=$ Image; and $\mathrm{X}=$ service quality. From this equation can be interpreted:

1) From the results of the regression equation above, a constant value of 14,342 is obtained. This value means that if the independent variable (quality of service) is constant or not going well, the value of the banking image is 14,342 scale/unit.

2) From the results of the regression equation above, the service quality coefficient value is 0.803 . This value indicates that each addition of one value of service quality will increase the value of the banking image by 0.803 , or in other words, if the service quality is getting better, then it will be followed by an increase in the image of the bank, which is getting better with an increase of 0.803 .

3) Then based on the regression equation above, the Adjusted R Square value of 0.662 is also obtained, which means the magnitude of the ability of the independent variables in explaining the variation of the dependent variable is $66.2 \%$, while the remaining $33.8 \%$ is influenced by other variables that are not included. in this model. 


\section{Hypothesis Test Results and Discussion}

Hypothesis testing in this study is basically done to prove whether the variables studied in the study have a relationship or difference between two group factors or independence in a situation (Ali, H., Limakrisna, N. 2013). Hypothesis testing in this study was conducted through $t$ test (partial).

From the results of the regression test in Table 1 above using SPSS 21.0, the t-count of the system quality variable is 10.580 , with a significance value of 0.000 , due to the significance level of $<0.05(0.000<0.05)$, it can be concluded that service quality has a significant effect. to the image of banking. This can be interpreted that the better the quality of services provided by the bank, then this will also be followed by the increasing image of the bank. On the other hand, the worse the quality of service provided, the worse the company's image will be.

According to Nurjanah, R and Mulazid, A.S (2018) image can be formed from optimal service quality. Because optimal service quality will give a good perception of the company, and is one of the success factors that can affect the increasingly fierce business competition that exists today. In addition, the Bank can differentiate itself from the increasingly fierce business competition at this time, it can also be done by providing quality services for its customers. This is supported by the opinion of Sicillia, M (2019) in her research which found that service quality affects the company's image.

Serving customers with excellent service is certainly very difficult. This is because in each of its services, the bank cannot as a whole perform services without errors. There are so many factors that give rise to errors that affect serving customers, such as errors from human resources, product errors, and other non-technical errors.

From the results of a survey conducted, the quality of service available at BNI KC Simpang Rimbo Jambi City can be categorized as good. In the sense that employees are able to provide a sense of security and comfort to customers, can understand customer needs, have service conformity with what was promised, have good facilities and have a good image in the eyes of customers.

Service quality encourages customers to establish a close relationship with the company, thus enabling the company to understand carefully the expectations and needs, which in turn will form a good image in the minds of customers. Corporate image helps consumers understand the products and services offered by the company, a good image impression can arise from the knowledge and experience of customers who have or have used the products or services of a bank (Suryaatmaja, AN, Suprapti, NWS, and Yasa, NNK, 2016 ).

\section{CONCLUSION}

Berdasarkan hasil penelitian dan pembahasan, maka dapat disimpulkan bahwa terdapat pengaruh yang signifikan kualitas pelayanan terhadap citra bank secara parsial. Hal ini dapat diartikan bahwa semakin baik kualitas pelayanan yang diberikan oleh pihak bank, maka hal ini akan diikuti pula dengan semakin meningkatnya citra bank. Sebaliknya semakin buruknya kualitas pelayanan yang diberikan, maka akan berdampak terhadap semakin buruknya citra sebuah perusahaan tesebut.

\section{BIBLIOGRAPHY}

Akbar, M.M., and Parvez, N. (2009). Impact of Services Quality, Trust, and Customer Satisfaction on Customer Loyalty, ABAC Journal, Vol. 29, No. 1, pp. 24-38. 
Ali, H. (2012). Membangun Citra Perbankan Melalui IT \& CRM Untuk Meningkatkan Loyalitas Nasabah. Yogyakarta: Hasta Cipta Mandiri.

Ali, H., dan Limakrisna, N. 2013. Metodologi Penelitian (Petunjuk Praktis untuk Pemecahan Masalah Bisnis, Penyusunan Skripsi, Tesis, dan Disertasi). Deeppublish: Yogyakarta.

Balmer, J. (1995). Corporate Branding and Connoisseurship. Journal of General Management, 21(1), 24-46.

Balmer, J., \& Stotvig, S. (1997). Corporate identity and private banking: a review and case study. International Journal of Bank Marketing, 15(5), 169-184.

Cornelissen, J. (2000). Corporate image: an audience centred model. Corporate Communications: An International Journal, 5(2), 119-125.

Gronroos, C. (2001). The Perceived Service Quality Concept - a mistake?. Journal of Managing Service Quality, Volume 11, No. 3, pp. 150-152, MCB University Press, London.

Jabnoun, N and Khalifa, A. (2005). A Customized Measure Of Service Quality In The UAE. Managing Service Quality, 15, 4.

Kasmir. (2007). Dasar-dasar Perbankan. Jakarta: Rajawali Pers.

Kotler, P. (2012). Manajemen Pemasaran. Jakarta: PT Indeks.

Kotler, P. dan Keller, K.L. (2012). Manajemen Pemasaran. Jilid 1 dan 2. Jakarta: PT Indeks.

Nurjanah, R dan Mulazid, A.S. (2018). Pengaruh Kualitas Pelayanan dan Corporate Social Responsibility terhadap Citra Perusahaan. Jurnal Muqtasid, 9(1).

Parasuraman, A., Valarie A. Zeithaml, and Leonard L. Berry. (1990). Delivering Quality Service : Balancing Customer Perceptions and Expectations. New York : THE TREE PRESS.

Schiffman, L.G., \& Kanuk, L.L. (2010). Consumer Behaviour (10th ed). New Jersey, Pearson Prentice Hall.

Simamora, E.S. (2007). Analisis Faktor-Faktor Yang membangun Kepuasan Nasabah Untuk Meningkatkan Loyalitas Pelanggan. (Studi Empiris Nasabah PT. Bank Tabungan Negara Cabang Semarang). Tesis Universitas Diponegoro Semarang.

Sicillia, M. (2019). Pengaruh Produk, Kualitas Pelayanan Terhadap Citra Perusahaan Yang Berdampak Terhadap Kepuasan Nasabah Pada Pt Bank Ocbc Nisp, Tbk Cabang Green Garden. Jurnal Pemasaran Kompetitif, Vol. 2, No. 2.

Supranto. J. ( 2011). Pengukuran Tingkat Kepuasan Pelanggan Untuk Menaikkan Pangsa Pasar. Jakarta: Rineka Cipta.

Suryaatmaja, A.N., Suprapti, N.W.S., dan Yasa, N.N.K. (2016). Pengaruh Kualitas Pelayanan Dan Citra terhadap Kepuasan dan Word Of Mouth nasabah. E-Jurnal Ekonomi dan Bisnis Universitas Udayana 5(7).

Worcester, R. M. (1997). Managing the image of your bank: the glue that binds. International Journal of Bank Marketing, 15(5), 146-152.

Yandi, A. (2019). Meningkatkan Kepuasan Nasabah Melalui Kualitas Pelayanan yang di Mediasi oleh Kepercayaan (Survey Pada BRI Kcp Unit Kuamang Kuning Kabupaten Bungo). JMAS (Jurnal Manajemen Dan Sains). https://doi.org/10.33087/jmas.v4i1.83 